\title{
THE IMPACT OF SHADOWING TECHNIQUE ON TERTIARY STUDENTS' ENGLISH PRONUNCIATION
}

\author{
RIO SUGIARTO', PRIHANTORO'2, SARWO EDY3 \\ Institut Agama Islam Negeri Curup' \\ Institut Agama Islam Negeri Curup ${ }^{2}$ \\ Institut Agama Islam Negeri Curup ${ }^{3}$ \\ riosugiarto255@gmail.com
}

DOI : http://dx.doi.org/10.29300/ling.v6i1.3298

Received: April 2020

Accepted: May 2020

Published: July 2020

\begin{abstract}
In the realm of English teaching and learning especially for those of non-native English users, English pronunciation instruction always calls for various techniques which can meet students' conditions that are naturally affiliated with their psychological and cultural complexities. Thus, the present study aimed at examining the impact of one of English pronunciation instruction techniques, the so-called shadowing technique, on tertiary students' English pronunciation at IAIN Curup, Bengkulu, Indonesia. An experimental study was conducted by engaging 40 tertiary English students selected randomly. They were split into two groups, wherein 20 students were taught English pronunciation using shadowing technique, and the rest 20 students were taught English pronunciation using a conventional technique. This study revealed that shadowing technique had a positive and significant impact on students' English pronunciation. Their English pronunciation improvement encompassed various components such as monophthongs, diphthongs, triphthongs, semi-vowels, consonants, consonant cluster sounds, strong and weak forms, linking phonemes, syllable stresses, word stresses, sentence stresses, rhythm, pitch and intonation. Further studies are expected to scrutinize the effect of shadowing technique on English pronunciation by involving more samples, making use of gender difference as a moderator variable, and testing the retention of English pronunciation improvement.
\end{abstract}

Keywords: English pronunciation, shadowing technique, tertiary English students

\section{INTRODUCTION}

In using English for communication, whether it takes place as a second or foreign language, pronunciation is part of speaking skill which cannot be neglected. Pronunciation, other than to beautify English conveyance during communication, serves as an element of meaning construction. Someone, whose English is not his native language, who utters an English utterance with less-intelligible pronunciation, will have big potential and possibility to offer improper meanings as he actually intends to (Cheung and Sung, 2014; Rahimi and Ruzrokh, 2016). Even when one phoneme is pronounced in an improper way, the offered meaning will alter (Shabani and Ghasemian, 2017). It is true that as a matter of fact pronunciation plays a pivotal role in English speaking.

The nature of English pronunciation can be defined as the acts of producing, receiving, and perceiving English sounds in which these sounds are an interrelated combination of both How to cite this article: Sugiarto, R., Prihantoro, P., \& Edy, S. (2020). The Impact of Shadowing Technique on Tertiary Students' English Pronunciation. Linguists : Journal Of Linguistics and Language Teaching, 6(1), 114125. doi:http://dx.doi.org/10.29300/ling.v6i1.3298 
segmental and suprasegmental sounds (Daton \& Seidlhofer, 1994; Richards \& Schmidt, 2002; Roach, 2009; Setter \& Jenkins, 2005; Susan \& Boyer, 2002). In this sense, the segmental sounds refer to English phonemes encompassing all types and modifications such as vowels, diphthongs, triphthongs, consonants, cluster sounds, and many others (Gilbert, 1994; Burgess $\&$ Spencer, 2000). Subsequently, the suprasegmental ones indicate wider aspects beyond the English phonemes such as stress and intonation including their varieties and modifications (Sewell, 2016; Szyszka, 2016).

However important English pronunciation is, there are some phenomena encountered amid tertiary students taking English major in their first college year at IAIN Curup. In this institute, although English pronunciation has been inserted in the curriculum of English department as one of the learning subjects, most of the students still face problems to successfully deal with English pronunciation. This condition can be viewed from the data of tertiary students' English pronunciation competence after getting tested in the preliminary study. The preliminary study was conducted with the help of English pronunciation lecturer who investigated students' problems as regards English pronunciation. The test revealed the conditions in which the average score the students got only reached 58, with 75 as the highest score, and 50 as the lowest score.

Such preliminary study data implied that a majority of students had difficulties in dealing with several important indicators of English pronunciation, in that most students found it difficult to appropriately pronounce English phonemes in terms of English diphthongs, fricative sounds, allophones, combinatory sounds, and linking sounds. Mostly, they also had difficulties in using appropriate word and sentence stresses, rhythm, pitch, and intonation. Furthermore, based on the preliminary observations made by the researchers and the English pronunciation lecturer, it was found that some students were not so active in the classroom, and they looked embarrassed as well as reluctant to engage into classroom activities as set by the lecturer.

The aforementioned problems were caused by several factors from both students and lecturer. In the preliminary study, the researchers aided by the English pronunciation lecturer also distributed questionnaires and conducted interviews with students to probe into some influential factors regarding their problems in English pronunciation. The questionnaires revealed that students' problems emerged due to many factors. First, students' native language or their vernacular made them difficult to pronounce English phonemes, words, phrases, clauses, or sentences properly. Second, their vernacular had many differences in syllable stresses, word stresses, sentence stresses, rhythm, and intonation so that they found it difficult to adapt English with proper pronunciation. Third, they were lack of independent exercises to improve English pronunciation at home. Fourth, they had insufficient techniques or methods Linguists: Journal of Linguistics and Language Teaching Vol. 6, No. 1, July 2020 
to scaffold their independent learning to practice and improve English pronunciation at home. Fifth, from the lecturer's side on the basis of students' perspectives, the learning process was implemented with too many theories related to phonology and phonetic but with limited practice. Sixth, the teaching method conveyed to students was still conventional with limited practical input. Seventh, the English pronunciation learning processes were not supported by essential media such as English audios or videos. In turn, eight, the limited practice set by the lecturer was not controlled properly so that many students were not involved into practice.

The above phenomena call for an effective technique of teaching English pronunciation so that students can improve their pronunciation better. There are many ways English teachers commonly apply to teach English pronunciation. To name a few, those ways are represented by some techniques such as phonetic transcription, auditory reinforcement, visual reinforcement, tactile reinforcement, drama voice techniques, audio feedback, and multimedia enhancement (Brown, 1992; Celce- Mauricia, 1996; Korkut and Çelik, 2018; Chen, Tian and Chen, 2020). However, there is one more sophisticated technique of teaching English pronunciation, but this one is quite rarely practiced by teachers of English as a foreign or second language. This one is called shadowing technique. One of the reasons is that this technique is quite challenging for students to be applied.

Initially, shadowing technique was designed to improve the ability to hear and speak (Yajima, 1988). This technique was introduced in Japan in 1970s. In order to attract students, it took about twenty years for this technique to be pedagogically recognized in the realm of language education such as English as a foreign language. The principle of shadowing technique aligns with McLaughlin's (1978) theory concerning information processing which positions second or foreign language learning as the controlled but automated processes. According to McLaughlin (1978), the process of acquiring a second language begins with stuttering language training, but over time, with good control, students will be able to automate the entire training processes. This principle underlies shadowing technique. Related to shadowing technique, Baddeley (1986) termed it as the use of sub-vocalization element to practice responsiveness in language acquisition. Tamai (1997) defines shadowing technique as a listening exercise in which students trace the words that are heard and repeat them as precisely as possible while listening attentively to the upcoming information. Baddeley (1986) proposes a working memory model that clearly illustrates the mechanism of maintaining memory and recognizing sounds.

According to the working memory model, shadowing is a process of intense cognitive work rather than just the act of imitating. When the input of utterances is received, the subvocalization of the utterances will be stored in short-term memory for approximately two 
seconds, and this input will not last. Shadowing technique utilizes the ability of short-term memory with this short duration as a medium to facilitate pronunciation and to practice fast response to process and to produce speech again. This short-term memory in the context of sub-vocalization of information is called the phonological loop. The following figure presents the phonological loop system.

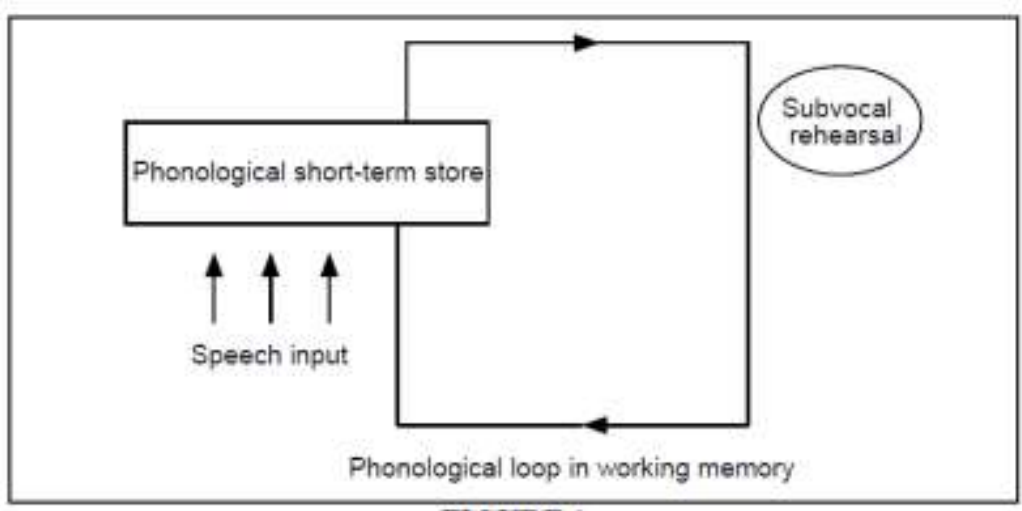

Figure 1. The System of Phonological Loop

Thus, the faster a person is able to sub-vocalize the speech input he receives, the more information he can save in his phonological loop, and the more massages he can comprehend (Nitani, 1999). The following figure illustrates an example of a shadowing technique process oriented towards the phonological loop domain.

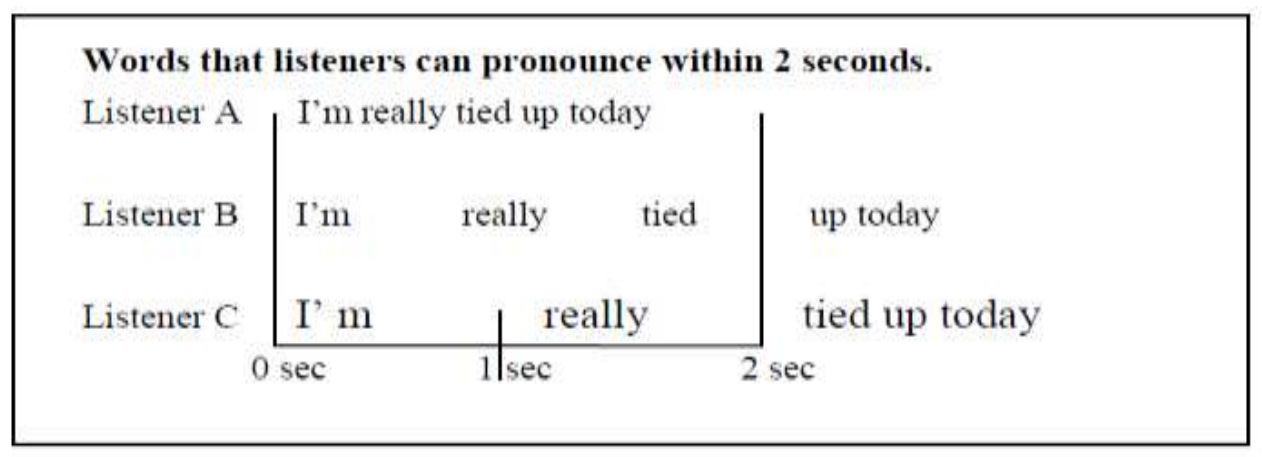

Figure 2. An Example of a Shadowing Technique Process

Based on the structure of phonological loop, shadowing is a task that entails deliberate sub-vocalization of speech input. A person must remember speech input and reproduce it in real time. It requires listening and speaking skills to function at the same time in order to be effective in improving his/her skills in listening comprehension, speaking, and conversational activity. Based on the concept of phonological loop, shadowing is a deliberate process of subvocalization. In this case, one must remember the input of utterances and reproduce them directly. To practice shadowing technique, students need to combine both listening and speaking skills at once.

A couple of studies pertinent to shadowing technique have been conducted. Shiota (2012) examined how shadowing technique affected novice college students' psychology, which was typically low on intrinsic motivation in grammar translation method and high on 

anxiety in communicative approach. Her study suggested that shadowing technique could be a useful technique to solve problems with regard to students' attitudes towards second language learning. Another study was carried out by Manseur (2014). In his study, he used a mix-method study to examine the effectiveness of shadowing technique and to explore the role of shadowing technique in the development of learners' speaking skill. His study resulted in that this technique was indeed effective in improving learners' English speaking skill. The role of shadowing technique was mostly found to work effectively in the areas of speaking skill. In addition, the other study using shadowing technique as its primary variable was also undertaken by Zakeri (2014). In his study, he examined the effect of shadowing technique on EFL learners' oral performance in terms of fluency. His study also proved that shadowing technique was effective in improving English speaking skill including its entire performance.

Nonetheless, the highlighted studies above did not specifically touch the element of English pronunciation as affected by the application of shadowing technique. On the other side, English pronunciation instruction calls for a sophisticated and effective technique to help scaffold students in an effort to improve their English pronunciation. Grounded in the importance of English pronunciation; the phenomena indicating some problems faced by tertiary English students of IAIN Curup in learning English pronunciation, and the theoretically promising concept of shadowing technique in improving English pronunciation, thus this study is conducted to examine the impact of shadowing technique on tertiary students' English pronunciation.

\section{METHOD}

This study applied a true experimental research to examine the impact of shadowing technique on tertiary students' English pronunciation. The experimental design adopted was a pretest-posttest control-group design (Gall, Gall and Borg, 2003; Creswell, 2007; Ary et al., 2010; Fraenkel, Wallen and Hyun, 2012). There were 40 participants engaged as the samples. They were selected randomly from 80 tertiary English students who learned English pronunciation in their first college year. The randomization was assigned in an equal way in terms of students' English pronunciation competence, level, ages, and gender, in this regard, 20 male and 20 female students. The 40 students were split into two groups, namely experimental and control groups. 20 students in the experimental group were taught using shadowing technique, and the rest 20 students in the control group were taught using a conventional technique as the lecturer commonly applied such as phonetic theories to practice.

The procedure of experimentation consisted of giving a pretest to students of both groups, teaching students English pronunciation using shadowing technique for those of the 
experimental group and using a conventional technique for those of the control group, and giving students of both groups a posttest. In detail, both pretest and posttest were designed in the form of reading aloud test recorded using video recorders, and the test scores would further be assessed resting upon the pronunciation rubric. For the treatments of both groups, either shadowing technique or the conventional technique was taught by an English pronunciation lecturer as the researchers' collaborative partner. In this sense, the researchers only received the data from the lecturer. Both shadowing and conventional techniques were implemented for eight meetings for the sake of gaining realistic data with respect to the curve of English pronunciation improvement. The following table 1 portrays the procedure of shadowing technique adopted from Hayakawa (2004) and that of a conventional technique.

Table 1. Procedures of shadowing and conventional techniques

\begin{tabular}{|c|c|c|c|}
\hline Step & Procedure of Shadowing Technique & Step & Procedure of Conventional technique \\
\hline 1 & $\begin{array}{l}\text { Listening: } \\
\text { Students work in group to listen to the CD and grasp } \\
\text { the outline of the contents without looking at the } \\
\text { textbook. The textbook used is "American accent } \\
\text { training" by Cook (2000). This textbook has the } \\
\text { audio CD to practice shadowing. }\end{array}$ & 1 & The lecturer explains the material. \\
\hline 2 & $\begin{array}{l}\text { Slash listening: } \\
\text { Students look at the textbook and mark the stressed, } \\
\text { unstressed syllables or words, or other } \\
\text { pronunciation points in the textbook using slashes } \\
\text { while listening. }\end{array}$ & 2 & $\begin{array}{l}\text { The lecturer gives examples of pronouncing the } \\
\text { learned words, phrases, and utterances. }\end{array}$ \\
\hline 3 & $\begin{array}{l}\text { Mumbling: } \\
\text { In group, students shadow the text (input speech) in } \\
\text { a low voice so that the students' own voices do not } \\
\text { disturb the speech sounds. }\end{array}$ & 3 & $\begin{array}{l}\text { The lecturer assigned students to work in group } \\
\text { to practice English pronunciation as well as to get } \\
\text { corrections from one another. }\end{array}$ \\
\hline 4 & $\begin{array}{l}\text { Parallel reading: } \\
\text { Students look at the textbook while listening to the } \\
\mathrm{CD} \text {, and check the textbook mainly focusing on the } \\
\text { points that they could not catch. }\end{array}$ & 4 & The lecturer tests students through drilling. \\
\hline 5 & $\begin{array}{l}\text { Understanding the meaning: } \\
\text { If students find any vocabularies, idioms and } \\
\text { construction of sentences that they do not know, } \\
\text { they will look up the meaning or pronunciation in a } \\
\text { dictionary. If there are some questions, those } \\
\text { questions will be discussed or answered by their } \\
\text { peers or lecturer. }\end{array}$ & 5 & The lecturer gives corrections to students \\
\hline 6 & $\begin{array}{l}\text { Prosody shadowing: } \\
\text { Students practice shadowing focusing on pitch, } \\
\text { rhythm, stresses, intonations, and entire } \\
\text { pronunciation without looking at the textbook. They } \\
\text { try to imitate particularly rhythm and intonation } \\
\text { repeatedly until they can shadow smoothly. They } \\
\text { must pay attention not to pronounce with their own } \\
\text { accents. }\end{array}$ & & \\
\hline 7 & $\begin{array}{l}\text { Content shadowing: } \\
\text { The goal is to shadow smoothly with understanding } \\
\text { the contents as well. }\end{array}$ & & \\
\hline 8 & $\begin{array}{l}\text { Recording: } \\
\text { Students record their shadowing using their mobile } \\
\text { phones. }\end{array}$ & & \\
\hline 9 & $\begin{array}{l}\text { Listen and compare: } \\
\text { Students listen their own shadowing and check with } \\
\text { the script. They compare their work with the } \\
\text { recording. If there is any weakness, they should } \\
\text { work more and improve on it. }\end{array}$ & & \\
\hline 10 & $\begin{array}{l}\text { Review / Reflect: } \\
\text { The lecturer reviews and reflects on the lesson orally } \\
\text { with learners. }\end{array}$ & & \\
\hline
\end{tabular}

Linguists: Journal of Linguistics and Language Teaching

Vol. 6, No. 1, July 2020 
Note: In the application of shadowing technique, the learning principle is student-centered. Thus, the lecturer's role is only to facilitate, help, control, and give learning reflections to students.

Both pretest and posttest were constructed in the form of a reading aloud test. The test was validated by getting corrections and suggestions from English lecturers having expertise in the field of test and evaluation subject, English phonology subject, and English linguistics subject. According to the validation results, the test was considered valid. Subsequently, the reliability of the test was measured using Alpha Cronbach formula. To reach the reliability score, the test was tried out to 20 tertiary English students who were not incorporated as the samples of the present study. The try-out results were measured using the rubric of English pronunciation so that the test results could be objectively calculated. The rubric was constructed by the English pronunciation lecturer of English department at IAIN Curup by grounding his review results vis-a-vis English pronunciation assessment from various experts such as Gilbert (2005); Kenworthy (1987); Morley (1991); Schaetzel (2009); Siertsema (1959); and Ur (1991). The following table 2 displays the rubric used.

Table 2. Rubric of English Pronunciation Assessment

\begin{tabular}{|c|c|c|c|c|c|c|}
\hline No & Indicators & $\begin{array}{l}\text { Ineffective } \\
\text { Pronunciation }\end{array}$ & $\begin{array}{l}\text { Partially } \\
\text { Effective } \\
\text { Pronunciation }\end{array}$ & $\begin{array}{l}\text { Satisfactory } \\
\text { pronunciation }\end{array}$ & $\begin{array}{l}\text { Good } \\
\text { Pronunciation }\end{array}$ & $\begin{array}{l}\text { Excellent } \\
\text { Pronunciation }\end{array}$ \\
\hline & & $(45-54)$ & $(55-64)$ & $(65-74)$ & $(75-84)$ & $(85-95)$ \\
\hline 1 & Phonemes & $\begin{array}{l}\text { Mostly inaccurate } \\
\text { while pronouncing } \\
\text { individual sounds } \\
\text { such as } \\
\text { monophthongs, } \\
\text { diphthongs, } \\
\text { triphthongs and } \\
\text { semi-vowel, } \\
\text { consonant, and } \\
\text { consonant cluster } \\
\text { sounds }\end{array}$ & $\begin{array}{l}\text { Inaccurate } \\
\text { pronunciation of } \\
\text { some individual } \\
\text { sounds such as } \\
\text { monophthongs, } \\
\text { diphthongs, } \\
\text { triphthongs and } \\
\text { semi-vowel, } \\
\text { consonant, and } \\
\text { consonant } \\
\text { cluster sounds }\end{array}$ & $\begin{array}{l}\text { Fairly accurate } \\
\text { pronunciation of } \\
\text { individual } \\
\text { sounds such as } \\
\text { monophthongs, } \\
\text { diphthongs, } \\
\text { triphthongs and } \\
\text { semi-vowel, } \\
\text { consonant, and } \\
\text { consonant } \\
\text { cluster sounds }\end{array}$ & $\begin{array}{l}\text { Mostly } \\
\text { Accurate } \\
\text { pronunciation } \\
\text { of individual } \\
\text { sounds such as } \\
\text { monophthong } \\
\text { s, diphthongs, } \\
\text { triphthongs } \\
\text { and semi- } \\
\text { vowel, } \\
\text { consonant, } \\
\text { and consonant } \\
\text { cluster sounds }\end{array}$ & $\begin{array}{l}\text { Native-like } \\
\text { pronunciation of } \\
\text { individual sounds } \\
\text { such } \\
\text { monophthongs, as } \\
\text { diphthongs, } \\
\text { triphthongs and } \\
\text { semi-vowel, } \\
\text { consonant, and } \\
\text { consonant cluster } \\
\text { sounds }\end{array}$ \\
\hline 2 & Allophones & $\begin{array}{l}\text { Mostly unable to } \\
\text { pronounce } \\
\text { particular sounds } \\
\text { needed to be } \\
\text { differently } \\
\text { pronounced when } \\
\text { placed in different } \\
\text { positions/sequenc } \\
\text { es }\end{array}$ & $\begin{array}{l}\text { unable to } \\
\text { pronounce some } \\
\text { of the particular } \\
\text { sounds needed } \\
\text { to be differently } \\
\text { pronounced } \\
\text { when placed in } \\
\text { different } \\
\text { positions/sequen } \\
\text { ces }\end{array}$ & $\begin{array}{l}\text { Fairly able to } \\
\text { pronounce } \\
\text { particular } \\
\text { sounds needed } \\
\text { to be differently } \\
\text { pronounced } \\
\text { when placed in } \\
\text { different } \\
\text { positions/sequen } \\
\text { ces }\end{array}$ & $\begin{array}{l}\text { Mostly able to } \\
\text { pronounce } \\
\text { particular } \\
\text { sounds needed } \\
\text { to be } \\
\text { differently } \\
\text { pronounced } \\
\text { when placed } \\
\text { in different } \\
\text { positions/sequ } \\
\text { ences }\end{array}$ & $\begin{array}{l}\text { Native like ability to } \\
\text { pronounce particular } \\
\text { sounds needed to be } \\
\text { differently } \\
\text { pronounced when } \\
\text { placed in different } \\
\text { positions/sequences }\end{array}$ \\
\hline 3 & $\begin{array}{l}\text { Combinatio } \\
\text { ns of Sounds }\end{array}$ & $\begin{array}{l}\text { Mostly unable to } \\
\text { differentiate } \\
\text { between strong } \\
\text { and weak form }\end{array}$ & $\begin{array}{l}\text { Unable to } \\
\text { differentiate } \\
\text { some of the } \\
\text { particular } \\
\text { sounds needed } \\
\text { to be produced } \\
\text { in strong or } \\
\text { weak form }\end{array}$ & $\begin{array}{l}\text { Fairly able to } \\
\text { differentiate } \\
\text { particular } \\
\text { sounds needed } \\
\text { to be produced } \\
\text { in strong or } \\
\text { weak form }\end{array}$ & $\begin{array}{l}\text { Mostly able to } \\
\text { differentiate } \\
\text { particular } \\
\text { sounds needed } \\
\text { to be produced } \\
\text { in strong or } \\
\text { weak form }\end{array}$ & $\begin{array}{l}\text { Having native-like } \\
\text { ability } \\
\text { differentiate } \\
\text { particular sounds } \\
\text { needed to be } \\
\text { produced in strong } \\
\text { or weak form }\end{array}$ \\
\hline
\end{tabular}




\begin{tabular}{|c|c|c|c|c|c|c|}
\hline 4 & $\begin{array}{l}\text { Linkage of } \\
\text { Sounds }\end{array}$ & $\begin{array}{l}\text { Mostly unable to } \\
\text { link phonemic, } \\
\text { morphemic, and } \\
\text { syntactic sounds }\end{array}$ & $\begin{array}{l}\text { Unable to link } \\
\text { some of the } \\
\text { phonemic, } \\
\text { morphemic, and } \\
\text { syntactic sounds }\end{array}$ & $\begin{array}{l}\text { Fairly able to } \\
\text { link phonemic, } \\
\text { morphemic, and } \\
\text { syntactic sounds }\end{array}$ & $\begin{array}{l}\text { Mostly able to } \\
\text { link } \\
\text { phonemic, } \\
\text { morphemic, } \\
\text { and syntactic } \\
\text { sounds }\end{array}$ & $\begin{array}{l}\text { Having native-like } \\
\text { ability to link } \\
\text { phonemic, } \\
\text { morphemic, and } \\
\text { syntactic sounds }\end{array}$ \\
\hline 5 & Stress & $\begin{array}{l}\text { Mostly unable to } \\
\text { sound appropriate } \\
\text { syllable, word, } \\
\text { and sentence } \\
\text { stress }\end{array}$ & $\begin{array}{l}\text { Unable to sound } \\
\text { some of the } \\
\text { commonly } \\
\text { appropriate } \\
\text { syllable, word, } \\
\text { and sentence } \\
\text { stress }\end{array}$ & $\begin{array}{l}\text { Fairly able to } \\
\text { sound } \\
\text { appropriate } \\
\text { syllable, word, } \\
\text { and sentence } \\
\text { stress }\end{array}$ & $\begin{array}{l}\text { Mostly able to } \\
\text { sound } \\
\text { appropriate } \\
\text { syllable, word, } \\
\text { and sentence } \\
\text { stress }\end{array}$ & $\begin{array}{l}\text { Having a native-like } \\
\text { ability to sound } \\
\text { appropriate syllable, } \\
\text { word, and sentence } \\
\text { stress }\end{array}$ \\
\hline 6 & $\begin{array}{l}\text { Rhythm and } \\
\text { Pitch }\end{array}$ & $\begin{array}{l}\text { Mostly unable to } \\
\text { lengthen and } \\
\text { heighten the } \\
\text { rhythm and pitch } \\
\text { of words or } \\
\text { expressions on the } \\
\text { basis of their } \\
\text { meaning and } \\
\text { function }\end{array}$ & $\begin{array}{l}\text { Unable to } \\
\text { lengthen and } \\
\text { heighten the } \\
\text { rhythm and } \\
\text { pitch of some of } \\
\text { the common } \\
\text { words or } \\
\text { expressions on } \\
\text { the basis of their } \\
\text { meaning and } \\
\text { function }\end{array}$ & $\begin{array}{l}\text { Fairly able to } \\
\text { lengthen and } \\
\text { heighten the } \\
\text { rhythm and } \\
\text { pitch of words or } \\
\text { expressions on } \\
\text { the basis of their } \\
\text { meaning and } \\
\text { function }\end{array}$ & $\begin{array}{l}\text { Able to } \\
\text { appropriately } \\
\text { lengthen and } \\
\text { heighten the } \\
\text { rhythm and } \\
\text { pitch of words } \\
\text { or expressions } \\
\text { on the basis of } \\
\text { their meaning } \\
\text { and function }\end{array}$ & $\begin{array}{l}\text { Having a native-like } \\
\text { ability when } \\
\text { lengthening and } \\
\text { heightening the } \\
\text { rhythm and pitch of } \\
\text { words or } \\
\text { expressions on the } \\
\text { basis of their } \\
\text { meaning and } \\
\text { function }\end{array}$ \\
\hline 7 & Intonation & $\begin{array}{l}\text { Mostly unable to } \\
\text { use intonations on } \\
\text { the basis of their } \\
\text { meanings and } \\
\text { functions }\end{array}$ & $\begin{array}{l}\text { Unable to use } \\
\text { some of the } \\
\text { commonly } \\
\text { important } \\
\text { intonations on } \\
\text { the basis of their } \\
\text { meanings and } \\
\text { functions }\end{array}$ & $\begin{array}{l}\text { Fairly able to } \\
\text { use intonations } \\
\text { on the basis of } \\
\text { their meanings } \\
\text { and functions }\end{array}$ & $\begin{array}{l}\text { Appropriately } \\
\text { able to use } \\
\text { intonations on } \\
\text { the basis of } \\
\text { their meanings } \\
\text { and functions }\end{array}$ & $\begin{array}{l}\text { Having a native-like } \\
\text { ability to use } \\
\text { intonations on the } \\
\text { basis of their } \\
\text { meanings and } \\
\text { functions }\end{array}$ \\
\hline
\end{tabular}

Based on the try-out results assessed using the above rubric, the reliability score of the pronunciation test was 0.85 which was higher than 0.74 . The foregoing showed that the English pronunciation test in the form of reading aloud test in tandem with the constructed rubric was reliable. The data were analyzed using paired t-test and independent t-test (Berger and Wong, 2009; Myers, Well and Lorch, 2010). The two formulas were deployed because the samples were normally distributed.

\section{RESULTS AND DISCUSSION}

The impact of shadowing technique on tertiary students' English pronunciation can be seen in table 3 below.

Table 3. The results of data analysis

\begin{tabular}{llllll}
\hline Group & Test & Mean & SD & N & Sig. \\
\hline Experimental Group & Pretest & 65.5 & 22.046 & 20 & 0.000 \\
& Posttest & 79 & 17.676 & 20 & 0.000 \\
Control Group & Pretest & 66 & 24.01 & 20 & 0.000 \\
& Posttest & 68.50 & 22.05 & 20 & 0.000 \\
\hline
\end{tabular}

Based on the table above, a significant difference was found between the pretest and posttest scores in the experimental group $(p=0,000<0.05)$. Similar to the results of the control group, there was a significant difference between the pretest and posttest scores $(p=0,000$ $<0.05)$. The average posttest scores obtained in both experimental and control groups were Linguists: Journal of Linguistics and Language Teaching Vol. 6, No. 1, July 2020 
higher than the pretest scores. The average score of the posttest in the experimental group was 79, while the posttest score in the control group was 68.50. For the pretest scores, the experimental group had a mean of 65.5 , and the control group had a mean of 66 . These findings indicated that shadowing technique had a positive impact on students' English pronunciation.

Based on the results of the independent sample t-test, a significant difference was found between the posttest results of both groups $(\mathrm{p}=0,000<0.05)$. The average posttest score found in the experimental group was 79 , which was higher than 68.50 representing the posttest score gained in the control group. These data were evident that students' English pronunciation improved better and in a significant way after being taught using shadowing technique compared to that of the conventional one. Hence, the foregoing data indicated that shadowing technique had a positive and significant impact on students' English pronunciation.

The present study revealed that shadowing technique has a positive and significant impact on Students' English pronunciation. The improvement of students' English pronunciation is represented by the posttest mean of 79 after they are taught by shadowing technique. Anchored in the interpretation described by the used rubric, the score 79 indicates that on average the students taught by shadowing technique have mostly accurate pronunciation of individual sounds such as monophthongs, diphthongs, triphthongs and semi-vowels, consonants, and consonant cluster sounds. They are mostly able to pronounce particular sounds needed to be differently pronounced when placed in different positions/sequences. They are mostly able to differentiate particular sounds needed to be produced in strong or weak forms. They are mostly able to link phonemic, morphemic, and syntactic sounds. They are mostly able to sound appropriate syllable, word, and sentence stresses. They are able to appropriately lengthen and heighten the rhythm and pitch of words or expressions on the basis of their meanings and functions. Subsequently, they are appropriately able to use intonations on the basis of their meanings and functions.

The present study supports the theory of second language acquisition as proposed by McLaughlin (1978), in which the process of acquiring a second language begins with stuttering language training, but over time, with good control, students will be able to automate the entire training processes. This principle underlies the work of shadowing technique. Shadowing technique, making use of the phonological loop representing a working memory system, illustrates the mechanism of maintaining memory and recognizing sounds (Baddeley, 1986). In such a way, the faster the students are able to sub-vocalize the speech input they receive, the more information they can save in their phonological loops, and the more massages they can comprehend (Nitani, 1999). This study proves that shadowing technique is successful in leading students to experience controlled but automated processes of English pronunciation 
learning (McLaughlin, 1978). This way helps students improve their English pronunciation in terms of many components such as monophthongs, diphthongs, triphthongs, semi-vowels, consonants, consonant cluster sounds, strong and weak forms, linking phonemes, syllable stresses, word stresses, sentence stresses, rhythm, pitch and intonation.

This study is limited to a small number of samples that are only 40 students engaged, and it seems that this small number does not generate any critical information in terms of gender difference. Perhaps, if a greater number of samples are incorporated, the improvement of English pronunciation due to being taught by shadowing technique can also be viewed from gender difference as a moderator variable. Accordingly, it is recommended that further studies be conducted to examine the effect of shadowing technique on students' English pronunciation by involving a huge number of samples so that the role of gender difference which mediates the extent of English pronunciation improvement can be identified. Further studies are also expected to test the retention of English pronunciation improvement affected by shadowing technique within a certain range of time.

\section{CONCLUSION}

This study revealed that shadowing technique has a positive and significant impact on tertiary students' English pronunciation. After students are taught using shadowing technique, on average, most of them have sufficiently accurate English pronunciation of individual sounds such as monophthongs, diphthongs, triphthongs, semi-vowels, consonants, and consonant cluster sounds. They are mostly able to pronounce particular English sounds needed to be differently pronounced when placed in different positions/sequences. They are mostly able to differentiate particular English sounds needed to be produced in strong or weak forms. They are mostly able to link English phonemic, morphemic, and syntactic sounds. They are mostly able to sound appropriate English syllable, word, and sentence stresses. They are able to appropriately lengthen and heighten the rhythm and pitch of English words or expressions on the basis of their meanings and functions. Subsequently, they are appropriately able to use intonations on the basis of their meanings and functions. Further studies are expected to scrutinize the impact of shadowing technique on tertiary students' English pronunciation by engaging more samples, incorporating gender as a moderator variable, and examining the retention of English pronunciation improvement.

\section{REFERENCES}

Ary, D. et al. (2010) Introduction to research in education. 8th edn, Measurement. 8th edn. USA: Wadsworth, Cengage Learning. doi: 10.1017/CBO9781107415324.004. 
Baddeley, A. D. (1986) Working memory. New York: Oxford University Press.

Berger, M. P. F. and Wong, W. K. (2009) An introduction to optimal designs for social and biomedical research. UK: John Wiley \& Sons Ltd.

Brown, A. (1992) Approaches to pronounciation teaching. London: Macmillan.

C., D. and Seidlhofer, B. (1994) Pronunciation. Oxford: Oxford University Press.

Celce- Mauricia, M. (1996) Teaching pronounciation. A reference for teachers of English speakers of other languages. UK: Cambridge University Press.

Chen, H. C., Tian, J. X. and Chen, H. C. (2020) 'Developing and evaluating a flipped corpusaided English pronunciation teaching approach for pre- service teachers in Hong Kong', Interactive Learning Environments. Taylor \& Francis, pp. 1-14. doi: $10.1080 / 10494820.2020 .1753217$.

Cheung, C. and Sung, M. (2014) 'Teaching the pronunciation of English as a lingua franca', Innovation in Language Learning and Teaching, 6(1), pp. 91-93. doi: 10.1080/17501229.2011.607918.

Cook, A. (2000) American accent training. USA: Matrix Press.

Creswell, J. W. (2007) Qualitative inquiry \& research design: Choosing among five approaches. 2nd edn. USA: SAGE publications, Inc.

Fraenkel, J. R., Wallen, N. E. and Hyun, H. H. (2012) How to design and evaluate research in education. 1221 Avenue of the Americas, New York, NY 10020: McGraw-Hill Companies, Inc. doi: 10.1017/CBO9781107415324.004.

Gall, M. D., Gall, J. P. and Borg, W. R. (2003) Educational research: An introduction. 7th edn. USA: Allyn and Bacon.

Gilbert, J. (1994) 'Intonation: A navigation guide for the listener (and gadgets to help teach it)', in Morley, J. (ed.) Pronunciation pedagogy and theory: New views, new directions. Alexandria, VA: TESOL.

Gilbert, J. B. (2005) Clear speech: Pronunciation and listening comprehension in North American English. New York: Cambridge University Press.

Hayakawa, S. (2004) 'Charge inversion mass spectrometry: Dissociation of resonantly neutralized molecules', InterScience, 39, pp. 111-135.

J., B. and Spencer, S. (2000) 'Phonology and pronunciation in integrated language teaching and teacher education', System, 28, pp. 191-215. doi: 10.1016/S0346-251X(00)00007-5.

Kenworthy, J. (1987) ‘Teaching English pronunciation'. London and New York: Longman.

Korkut, P. and Çelik, Ö. (2018) 'Developing pronunciation through creative drama', The Language Learning Journal. Taylor \& Francis, pp. 1-13. doi: 10.1080/09571736.2018.1491058.

Manseur, R. (2014) Exploring the role of shadowing in the development of EFL learners' speaking skill. Muhamed Keider University of Biskara.

McLaughlin, B. (1978) 'Second language acquisition in childhood'. Hillsdale, N.J.: Erlbaum. 
Morley, J. (1991) 'The pronunciation components in teaching English', TESOL Quarterly, 25(3).

Myers, J. L., Well, A. D. and Lorch, R. F. (2010) Research desgin and statistical analysis. New York: Routledge.

Nitani, K. (1999) Change, understand how to teach. Tokyo: Gakugei Tosho.

Rahimi, M. and Ruzrokh, S. (2016) 'The impact of teaching Lingua Franca Core on English as a foreign language learners' intelligibility and attitudes towards English pronunciation', Asian Englishes. Routledge, 18(2), pp. 1-16. doi: 10.1080/13488678.2016.1173466.

Richards, J. C. and Schmidt, R. (2002) Language teaching and applied linguistics. 3rd edn. UK: Pearson Education Limited.

Roach (2009) English phonetics and phonology: A little encyclopedia of phonetics. Cambridge: Cambridge University Press.

Schaetzel, K. (2009) Teaching pronunciation to adult English language learners. Washington, DC: Georgetown Law Center.

Setter, J. and Jenkins, J. (2005) 'State-of-the-art review article', Language Teaching, 38(1), p. 17.

Sewell (2016) English pronunciation models in globalized world: Accent, acceptability, and Hongkong English. Singapore: Singapore Association for Applied Linguistics. Routledge.

Shabani, K. and Ghasemian, A. (2017) 'Teacher's personality type and techniques of teaching pronunciation', Cogent Education. Cogent, 5(1), pp. 1-16. doi: 10.1080/2331186X.2017.1313560.

Shiota, K. . (2012) 'The effectiveness of shadowing on students' psychology in language learning', Accents Asia, 5(1), pp. 71-83.

Siertsema, B. (1959) A test in phonetics. Netherlands: Martinus Nijhoff, The Hague.

Susan and Boyer (2002) Understanding English pronunciation: an integrated practice course. Boyer Educational Resources.

Szyszka, M. (2016) Pronunciation learning strategies and language anxiety. UK: Springer International Publishing.

Tamai, K. (1997) 'How to rank shadowing in the respect of its effectiveness and process of listening comprehension', Current English, 36, pp. 105-116.

Ur, P. (1991) A course in language teaching from practice to theory. UK: Cambridge University Press.

Yajima, T. (1988) 'Interpreting training' application to English education I-Shadowing', English Learning, 21, pp. 29-37.

Zakeri, E. (2014) 'The effect of shadowing on EFL learners' oral performance in terms of fluency', International Journal of English Language Teaching, 2(1). 